\section{A Swiss biologist in Brazil between Rio de Janeiro and Amazonia at the fin-de-siècle}

\section{By Marinus S. Hoogmoed}

Ph.D. in Mathematics and Natural Sciences at University of Leiden, Netherlands. Associate Researcher at Emilio Goeldi Museum of Pará (marinus@museu-goeldi.br)

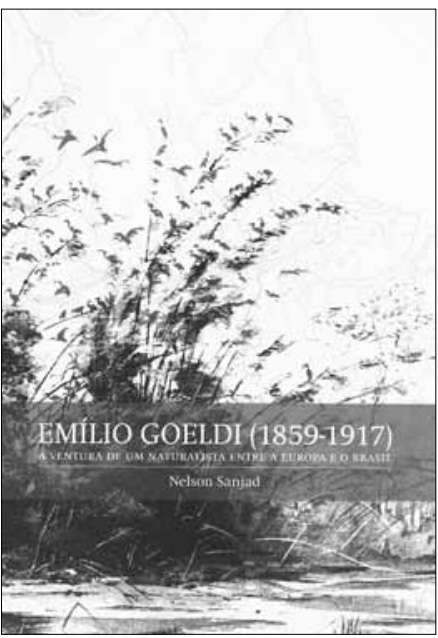

SANJAD, Nelson. Emílio Goeldi (1859-1917): a ventura de um naturalista entre a Europa e o Brasil. Versão para o francês de Janine Houard. Rio de Janeiro: EMC Edições, 2009. 232p. il. ISBN 978-85-87933-22-5

In the $150^{\text {th }}$ year of Emil August Goeldi's anniversary (August $28,1859)$, several events were planned in his honour, starting in February 2009 with a Belém 'samba school' taking as its motif for this year's samba and for decoration of its floats, Emil Goeldi and the Museu Paraense Emílio Goeldi (MPEG). The school won third place in this years ranking, despite the fact that in the text of the samba Emil Goeldi was described as a "jovem cientista, zoólogo, naturista" (young scientist, zoologist, naturist). Apparently the difference between a naturalist and a naturist had escaped the attention of the songwriter, but the samba was a success.

Other activities planned for this year by the MPEG in Belém are an exhibition about Goeldi, the publication of a catalogue of the photo collection of MPEG that was started by Goeldi, the three issues of the "Boletim do Museu Paraense Emílio Goeldi. Ciências Humanas" will be dedicated to Goeldi, with the April issue being dedicated to the history of archeology in the Amazon basin, with three texts published by Goeldi in German translated into Portuguese, and finally there are plans for a small symposium about Brazilian-German relations in science, also dedicated to Goeldi.

Nelson Sanjad, director of Communications of MPEG, trained as a journalist and a science historian, and with a vast knowledge of MPEG's history, contributes to the honours to be bestowed upon Goeldi this year by a very well written and illustrated biography that deals with all aspects of Goeldi's scientific and politic life, and with some flashes of his more personal family life.

The book is well executed. The jacket consists of a superposition of a colourplate of Goeldi's "Álbum de Aves Amazônicas", showing a colony of red ibis, on top of a map in grey of the lower Amazon river. The layout of the book is attractive, with 21 pages in full colour (some of them showing species described by Goeldi) and many more with black and white figures. Many pages have a figure in the background, with other figures or text superimposed on it, providing a lively environment. Pictures may represent photo's or drawings of animals, landscapes, floor plans, letters, pages from journals or books and portraits, taken from historical publications (mostly by Goeldi), and from the archives of MPEG, but also from the archives of the Brazilian Ministry of Foreign Affairs. Nelson Sanjad writes in a clear and pleasant style that makes reading a relaxing exercise, helped by the visual attractiveness of the layout.

The book is divided in two parts. The first part ("Itinerary") is a classical biography, dealing with many aspects of Goeldi's life from birth to death. This part is subdivided in the following chapters: New roads; Doctorate and applied science; Moving to Rio de Janeiro; Applied zoology in agriculture; Conflicts in the museum; Kolonistentyrann; Research in the Serra dos Orgãos; In the Museu Paraense; Building a scientific colony; Ties with the elite and the population; House of German studies; French-Brazilian border conflict: Goeldi between science and politics; From glory to dismissal from the Museu Paraense; Return to Switzerland. 
The second part ("Scientific career") is a more profound study of Goeldi's scientific life and thinking, based on his publications and on correspondence. It is subdivided in the following chapters: First subjects of study; Scientific project for the Museu Paraense; History in the Museu Paraense; Evolutionary studies; New area: medical entomology; Goeldi and the racial question in Brazil; Popularization of science; Emilio Goeldi at the frontier of knowledge.

The text is studded with numerous notes, referring to literature or archived documents. The notes are assembled after each part. The text is followed by a bibliography divided in three parts: the first one containing Goeldi's publications, arranged by type (books; chapters in books; scientific and popular articles in journals; reports, in memoriams, letters and other printed material; translations, and published lectures), the second part listing publications about Goeldi, many (seven of 33) by Nelson Sanjad, and the third part listing other references mentioned in the text.

On page 177 commences the French translation (of the entire text and all notes, but not of the legend of the figures). Translations into English and German are envisaged. Considering Goeldi's international network (mainly in German speaking Europe, but also in England) and importance in many fields, such translations would be very welcome.

Emil August Göldi was born August 28, 1859 in Switzerland. Just after obtaining his doctor's degree he was invited in 1884 to become leader of the zoology section of the National Museum in Rio de Janeiro. In Brazil he changed his name to Emílio Augusto Goeldi and started working on varied subjects, ranging from taxonomy to agricultural entomology, and from natural history observations to anatomy, of very diverse groups of animals. Towards the end of the 1880's there were some political troubles in the museum and Goeldi's contract was not renewed. From 1890-1892 Goeldi was leader of a colony of Swiss immigrants near Teresopolis, a job in which he was not very successful, probably because he paid more attention to the local fauna than to his administrative duties. In 1894 he was invited to become director of the Museu Paraense, a job he accepted with much enthousiasm, because he considered this a good opportunity to give a good impulse to the study of the fauna of Brazil, especially Amazonia. He started his job by defining the goals of the museum (study and divulgation of natural sciences and ethnology) and to discard a number of collections that did not fit the field of interest of the museum. $\mathrm{He}$ intended to reach the goals of the museum by making scientific collections, by public lectures, and by publications (by the end of 1894 the first Boletim of the museum was already published). Apart from the scientific sections of the museum a zoo and a botanical garden were created and he intended to establish biological stations along the Amazon and the Atlantic coast of Pará (this only happened in 1993 with the inauguration of the Scientific Station Ferreira Penna in National Forest of Caxiuanã). Goeldi contracted a number of central European scientists, taxidermists and artists, all German speaking, to serve in the scientific departments of the museum, which, as Nelson Sanjad vividly describes, became a small Central European settlement transplanted in Belém, with lakes in the form of the Lago Maggiore and the Black Sea and houses in Central European style. During his time at the Museu Paraense, Goeldi maintained vivid contacts with numerous European scientists, to whom he sent much material for identification, and invited them to publish in the museum's journals. During 1898-1900 a border conflict between France and Brazil concerning the northern part of the state of Amapá was laid before an international forum and the Swiss president was elected to judge the matter. Goeldi in that period made a trip to the contested area, reporting on many aspects of it and finally this report (which was officially presented by Brazil to the judge), and probably also Goeldi's personal acquaintance with the Swiss experts responsible for the analysis of reports presented by Brazil and France, resulted in a favourable decision

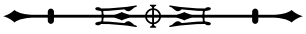


for Brazil. One month after this the governor of Pará rebaptised the Museu Paraense in Museu Goeldi, a name it would keep for about 30 years, when its name was changed into Museu Paraense Emílio Goeldi, the name it still has. Goeldi in the early years of the $20^{\text {th }}$ century tried to construct a new museum building, but this was never realized. Sanjad presents drawings and the floor-plan of the building to be, that show a very European type of museum.

Goeldi's scientific work ranged wide and far, from insects to vertebrates, from medical entomology to agricultural entomology, from strictly scientific publications to divulgation, from the registration of climatic data to the description of Indian artifacts. While in the Museu Paraense, Goeldi made several fieldtrips to different parts of the lower Amazon to collect material for the museum and for his studies. The collections of the museum increased greatly and also much material was sent abroad for examination by specialists. During Goeldi's stay at the museum the number of visitors rose spectacularly, from a mere 972 in 1894 to a spectacular 124.670 in 1907. After his return to Switzerland Goeldi was attached to the University of Bern and wrote several papers on genetics and evolution. Taking into account that Goeldi visited Europe several times for periods of months during his stay at Museu Paraense and made fieldtrips in Amazonia as well, his productivity is amazing, not only because of the number of publications, but also because of the varied subjects he addressed. Besides publishing many articles, he also maintained a vivid correspondence with a large number of European scientists, presented talks in Belém and at congresses in Europe, and actively participated in local matters.

Nelson Sanjad did a thorough job and gives us a good insight in the person of Emil Goeldi and especially in his scientific motives. He shows the importance of Goeldi for the basal biodiversity inventory work done in the Museu Paraense at the end of the $19^{\text {th }}$ and the beginning of the $20^{\text {th }}$ century. Work that at the moment fortunately is being continued by local Brazilian researchers.
For future editions, I would like to make some suggestions of data to be added to the text. From the text it is clear that Goeldi was instrumental in the description of more than 300 new species, but that he himself described only 13. These 13 species are listed in the text. The other new species were described by about 30 European specialists that received material from Goeldi for study. It would be good to have a listing of those species with their authors and years included. Apparently the data are available (generally assembled by Goeldi himself) and it would be good to publish them. Many of those new species must have been described in honour of Goeldi, but a listing of those patronyms is missing and its inclusion in future editions would be a valuable asset. From my own field of expertise (herpetology) I know of three species of Brazilian frogs that have been named after Goeldi: Bufo granulosus goeldii (Gallardo, 1965), Flectonotus goeldii (Boulenger, 1895), and Megaelosia goeldii (Bauimann, 1912). I also found three species of Brazilian fishes dedicated to Goeldi: Cheirocerus goeldii (Steindachner, 1908), Hemiodus goeldii (Steindachner, 1908), and Trichomycterus goeldii (Boulenger, 1895). It should not be too difficult to obtain, with the help of specialists, a larger list when other animal groups and plants are included as well.

Although my impression of the book is very favourable, I need to be critical about some aspects. For a biologist it is rather strange to see the lists of references presented in reversed chronological order, that is, the most recent publication listed first, the oldest listed last. It makes for some unexpected searches. However, in Humanities this seems to be an accepted way to cite references.

Nelson Sanjad (p. 18) states that Goeldi wrote his thesis on three European "harnessed" fishes. This is not correct on two accounts: only the last two are European, Loricaria cataphracta is an Amazonian species, and Balistes capriscus does not have a body covered by large bony plates (harness) as the two other species. The problem apparently is due to a wrong translation of the word Deckknochen as harness, but which here 
refers to the superficial bones of the head and shoulder girdle and not to the large bony plates that cover the body of two of the species studied.

Nelson Sanjad and the Publisher are to be congratulated for the timely publication of this interesting and well founded book, which shows that many matters that had Goeldi's attention (e.g. the low number of scientists working in the Amazon area, nature conservation) still are current. Now that we have a better insight in the enormousness of the biodiversity of Amazonia, we again realize that the number of scientists, Brazilian and foreign alike, studying biodiversity (taxonomy, ecology) in the Amazon area is still far below the number that is really needed to get to grips with the biodiversity around us and the forces destroying it rapidly at this very moment. I hope that by tracing back the original project, as envisaged by Goeldi and clearly presented by Nelson Sanjad, that lay at the basis of the Museu Paraense, scientists may become stimulated to direct more (or all of) their attention to this neglected area that is suffering under an enormous human impact, that seems hard to control because of political and economic interests that seem to prevail about the integrity and wise use of the Amazon rain forest. 